\title{
Viagens e itinerários dos imperadores romanos: uma entrevista com Ana Teresa Marques Gonçalves
}

Travels and itineraries of the Roman emperors: an interview with Ana Teresa Marques Gonçalves

\section{Ana Teresa Marques Gonçalves*}

Ana Teresa Marques Gonçalves é professora titular do Departamento de História da Universidade Federal de Goiás, bolsista produtividade do CNPq (nível 2) e coordenadora do Grupo de Pesquisa Leir/GO. Possui graduação em História pela Universidade Federal do Rio de Janeiro (1991), mestrado em História Social pela Universidade de São Paulo (1997) e doutorado em História Econômica pela mesma instituição (2002). Desenvolve pesquisa, orienta e possui uma vasta publicação científica na área de História Antiga, com ênfase em História da Roma Antiga, atuando principalmente nos seguintes temas: Roma, Período Severiano, poder, imaginários sociais e propaganda.

1. Thiago Eustáquio Araújo Mota: Saudações, Professora Ana Teresa, em primeiro lugar, gostaria de agradecer a disponibilidade de conceder esta entrevista para o número 18 de Romanitas - Revista de Estudos Grecolatinos. Cabe lembrar que um dos objetivos de entrevistar acadêmicos brasileiros é construir uma memória sobre a pesquisa em História Antiga no Brasil. Sendo assim, gostaria que começasse falando um pouco de sua trajetória acadêmica, da graduação ao mestrado. Como surgiu o seu interesse pelo Período Severiano?

Ana Teresa Marques Gonçalves: Antes de mais nada, gostaria de expressar minha alegria de participar da edição de número 18 de Romanitas, que vem se estabelecendo como um dos principais veículos de divulgação das conclusões de pesquisas em História Antiga realizadas no Brasil e no exterior. Minha mãe era professora primária e fui criada vendo-a preparar aulas e corrigir tarefas. Assim que comecei a andar, já a ajudava com o mimeógrafo e com a correção dos exercícios e passei a encarar tais tarefas como parte das brincadeiras cotidianas. Sempre quis ser professora. Enfileirava a meia dúzia

*Entrevista concedida a Thiago Eustáquio Araújo Mota em 9 de maio de 2021. 
de bonecas que tinha sobre a cama de casal da casa de meus avós maternos, onde passava as tardes, após as aulas matutinas, e inventava aulas para elas, reproduzindo o conteúdo que tinha aprendido no dia. Enquanto amigas minhas de infância gostavam de "brincar de casinha", eu repetia o que tinha aprendido na escola onde estudava para as minhas bonecas... Elas tinham atividades para fazer e até mesmo um boletim mensal, com notas e tudo... No ensino médio, apaixonei-me pelas aulas de História. Gostava principalmente dos relatos dos viajantes estrangeiros que passaram pelo Brasil nas épocas da Colônia e do Império. Ganhei de presente de aniversário de meu avô, Raul, os volumes da Enciclopédia Saga, referentes à História do Brasil, e passei a lê-los à noite como se fosse um romance... Em 1987, entrei no curso de História na UFRJ. Na época, eram 4 anos de bacharelado e mais 1 ano de licenciatura. Logo no segundo semestre, encantei-me com as aulas de Grécia ministradas por Neyde Theml e acabei me tonando monitora de História Antiga II, Roma, sob orientação de Norma Musco Mendes. Encantei-me pelo estudo das civilizações antigas clássicas e resolvi me especializar no tema. Meu TCC foi sobre as representações dos príncipes romanos nos breviários de Eutrópio e Aurélio Vítor, produzidos no século IV. A USP, à época, era o sonho de todos os estudantes de Antiguidade, pois, na Pós-Graduação, poder-se-ia ter acesso a professores especializados em Filosofia Antiga, Letras Clássicas, Arqueologia... Mudeime para São Paulo em 1992, para morar numa vaga num pensionato para moças e fazer o mestrado no Programa de História Social, sob orientação de Maria Luíza Corassin. Foi escolhendo o tema de mestrado, ao ler a tese de doutorado da futura orientadora, que conheci os Severos. Comprei num sebo da Rua do Ouvidor, no Rio, um livro do Gaston Boissier sobre a oposição aos imperadores, no qual ele defendia que não havia oposição organizada a eles... Mas eu tinha acabado de começar a ler os documentos textuais e verificava que somente Septímio, inaugurador do período severiano, tinha morrido de doença... Todos os outros soberanos tinham sido assassinados... Difícil sustentar que não havia oposição, mas se tornou meu objetivo entender como esta oposição se articulou, como agiu, como conseguiu derrubar os príncipes, quais grupos sociais pertenciam a ela... Assim, surgiu minha dissertação de mestrado.

2. A tese 'A construção da imagem imperial: formas de propaganda nos governos de Septímio Severo e Caracala', de sua autoria, é uma importante referência para a História Antiga nacional e também estrangeira. Gostaria que comentasse um pouco sobre o período do doutorado, o estágio de pesquisa na École Française de Rome e a experiência, recente, de publicar o trabalho em formato de livro. 
R: A tese de doutorado, construída na USP, junto ao Programa de História Econômica, sob orientação de Norberto Luiz Guarinello, acabou sendo um prolongamento da dissertação. Enquanto no mestrado analisei somente documentos textuais, que me permitiram identificar as formas de oposição aos imperadores severianos, como motins militares, conspirações palacianas, entre outras, na tese pude me aprofundar nas formas de sustentação de um príncipe no comando imperial, incluindo na pesquisa informações advindas de suportes arqueológicos e imagéticos, como arcos do triunfo, templos, termas, moedas, inscrições epigráficas, entre outros. Consegui acesso aos catálogos numismáticos e epigráficos e aos relatórios de escavação em 2000, quando, em Roma, tive acesso aos maravilhosos acervos da Escola Francesa, da Escola Inglesa e da Academia Americana. Atualmente, tudo se encontra disponível em sítios da internet, ao sabor de um toque, mas na época só conseguíamos acesso a este tipo de material em viagens e estágios de pesquisa no exterior. Nos últimos anos, consegui apoio para publicar tanto a tese quanto a dissertação pela Paco. Sempre estimulo os meus orientandos a desenvolverem algum tipo de estágio e/ou missão de estudo no exterior, para que possam ter acesso aos sítios arqueológicos, pois conseguimos hoje baixar muitos livros cujo acesso antes só era possível em visitas a bibliotecas estrangeiras, mas nada, na minha opinião, ainda consegue substituir uma visita a um sítio arqueológico, mesmo com toda a tecnologia em $3 \mathrm{D}$ e em reconstrução virtual dos monumentos antigos.

3. Estivemos, em janeiro de 2019, na exposição 'Roma Universalis. L'Impero e la dinastia venuta dall'Africa. I Severi', organizada no espaço do Coliseu. Como foi reencontrar, em um mesmo local, vários bustos, estátuas e objetos que analisou na tese? Me recordo que adquiriu o catálogo da exposição e tem utilizado o material em pesquisas recentes.

R: As visitas ao exterior também possibilitam o acesso a este tipo de exposição e a aquisição dos catálogos, que muitas vezes não estão disponíveis de outra forma. Desde que conquistei uma bolsa produtividade em pesquisa do CNPq (nível 2) tenho buscado usar esta verba para missões de estudo no exterior. Já visitei sítios arqueológicos romanos, pré-romanos e greco-romanos na Europa (Portugal, Espanha, Inglaterra, França, Alemanha, República Tcheca, Eslováquia, Hungria, Áustria, Malta, Grécia, Itália/Sicília, etc...) e no Norte da África (Egito, Tunísia e Marrocos). Em cada visita, além do acervo fotográfico, busco adquirir catálogos e bibliografia concernente aos sítios visitados, além de conhecer os acervos dos museus arqueológicos e históricos existentes em cada região. O material adquirido tem auxiliado em minhas pesquisas e na melhoria da qualidade de minhas aulas ministradas junto aos cursos de graduação e pós-graduação em História na 
UFG, onde trabalho desde 1995. É sempre uma emoção poder observar de perto peças que somente havia visto em livros! Uma das viagens a Portugal, por exemplo, permitiume conhecer o sítio arqueológico pré-romano de Citânia de Briteiros, além do museu correlato, e dos sítios arqueológicos e dos acervos museológicos de Oeiras, Guimarães e Braga. Na Tunísia, além do famoso Museu do Bardo e do menos conhecido museu de Hadrumentum, e de seus renomados mosaicos, pude adquirir a obra completa do bispo Cipriano de Cartago, que atualmente é a base textual de minha bolsa de produtividade do CNPq, vigente até 2024.

4. Como docente do PPGH da Universidade Federal de Goiás e 39 orientações concluídas entre dissertações de mestrado e teses de doutorado, você pôde vivenciar e contribuir para a expansão da área no país. O que mudou na forma de pesquisar História Antiga no Brasil, considerando as três últimas décadas?

R: Depois da ministração de aulas, o que mais gosto no mundo acadêmico é o empreendimento da orientação de alunos, tanto em iniciação científica, quanto em programas de mestrado e doutorado. É a sensação de plantar uma sementinha e de vê-la crescer paulatinamente... Sempre reitero que meus orientandos são minha maior contribuição para a expansão e permanência da área de História Antiga em nosso país. Adoro vê-los bem formados, fazendo concursos para outras universidades e tendo seus próprios orientandos! É o milagre da multiplicação dos saberes! Atualmente, temos especialistas em História Antiga em quase todas as instituições superiores de ensino no Brasil, públicas e privadas. Multiplicaram-se também os programas de pós-graduação, e com eles as revistas especializadas em Antiguidade e os eventos acadêmicos, nos quais podemos reencontrar os amigos e integrar debates temáticos. A pandemia que inviabilizou nossa missão de estudos às ilhas gregas e minha viagem ao Irã, também possibilitou a eclosão de incontáveis eventos efetuados de forma remota. Pude contar com a presença virtual de Carlos Augusto Machado diretamente da Escócia na banca de qualificação de um doutorando, por exemplo. É impossível realizar uma pesquisa atualmente sem acesso à internet... Mas, continuo defendendo que meus orientandos visitem presencialmente os sítios históricos e arqueológicos sempre que possível.

5. Tendo em vista o dossiê 'Viagens, expedições e itinerários no Mediterrâneo Antigo' e sua vasta expertise no recorte do Principado, pretendo direcionar as perguntas para o tema das viagens dos imperadores. Quando as viagens às províncias e aos limites do Império se tornaram uma prática recorrente da agenda política dos governantes romanos? Dentro da 
economia das honras, para citar um conceito do historiador inglês Jon Lendon, a proposta seria fortalecer as fidelidades das elites provinciais e municipais?

R: Já na República romana, temos senadores que viajavam para visitar as propriedades que possuíam ao longo do território conquistado pelos romanos nas auréolas do Mar Mediterrâneo; temos comerciantes que singravam mares e rios e percorriam rotas terrestres, tão antigas e importantes quanto a rota da seda, por exemplo; temos soldados que se movimentavam para a participação em atividades bélicas empreendidas em várias regiões; temos magistrados que viajavam para ocupar cargos em diversas províncias que estavam sendo estabelecidas (por exemplo, os pretores peregrinos, que levavam as leis romanas aos mais recônditos territórios, que passavam então a contar com a presença administrativa dos romanos); temos cidadãos exilados e/ou banidos; temos escravos fugidios (lembremos da viagem de Espártaco, que queria voltar para sua pátria, na Trácia)... Ou seja, viagens e expedições eram ações contínuas no território romano em todos os regimes políticos. Esta prática permaneceu no Principado. Com a extensão máxima dos limites imperiais durante o governo de Trajano, após as vitórias conquistadas nas guerras dácicas, a definição dos limites imperiais e o estabelecimento da formatação das províncias permitiram que mais viagens ainda fossem empreendidas por soldados, comerciantes, proprietários de terras e de escravos, dentre outros. Lembro-me das cartas de Plínio, o Jovem, nas quais ele relata as viagens empreendidas para visitar suas propriedades espalhadas por várias províncias. Lembremos da concessão de tropas e poderes dada pelo Senado a Pompeu para combater os piratas no Mar Egeu, que estavam desorganizando o comércio e as demais viagens na região, que conhecemos pela obra de Cícero. O empreendimento de viagens era fundamental para a administração do Império, seja na República, seja no Principado. Quase todos os imperadores empreenderam viagens, mais longas ou mais curtas, com múltiplos interesses. Dentre os principais objetivos, podemos destacar o conhecer e se fazer conhecer por governadores, membros das elites provinciais e generais estacionados nas províncias, visando a gerar a cooptação e a lealdade destes estratos; participar de batalhas; integrar ritos e cerimônias religiosas, dentre outras festividades; conhecer monumentos; etc... A título de exemplo, Septímio morreu, oficialmente de gota, em Eburacum, atual York, na Inglaterra, para onde havia viajado, junto com esposa, filhos e vários integrantes da aula Caesaris, para combater invasões ao território imperial. Antes, ele havia visitado o túmulo de Alexandre, o Grande, no Egito. Seu filho e herdeiro Caracala também esteve em Alexandria, segundo Dion Cássio, e morreu assassinado, voltando de uma visita a um templo dedicado a Cibele. Adriano perdeu seu amado Antínoo afogado durante uma cerimônia realizada no Rio 
Nilo, no Egito, no decorrer de uma viagem ao Oriente. O mesmo Adriano esteve na Grécia para se iniciar nos Mistérios de Elêusis, prática esta realizada por diversos príncipes. Tibério optou por viver mais na ilha de Capri do que em Roma, em seu palácio insular. Trajano estava lutando contra os germanos quando foi aclamado imperador e teve que fazer uma longa viagem até Roma para se apresentar ao Senado, que durou dois anos. Interessante relembrar que estes soberanos viajavam muitas vezes com membros da família imperial e com cortesãos diversos, e sempre cercados de membros da guarda pretoriana. As cidades eram avisadas com antecedência destas viagens e se engalanavam para receber os Príncipes, em passagem para algum reconhecimento ou empresa militar. Muitas construções que nos restaram para análise foram produzidas para receberem a visita do príncipe em viagem. Temos vários arcos dedicados aos Severos no norte da África que foram erigidos para comemorar a concessão de benesses imperiais estabelecidas durante viagens a estes territórios. Sem as viagens constantes de magistrados, soldados e comerciantes, o império territorial administrado pelos romanos não teria se mantido unido por tanto tempo.

6. De que maneira essas viagens eram divulgadas, no sentido da 'propagatio', ou formavam uma memória visual permanente? Havia algo semelhante a um diário de viagens?

R: Havia uma correspondência constante entre os administradores imperiais e os membros da elite romana. Sabemos disso pelas cartas de Cícero, Sêneca e Plínio, por exemplo. Numa das cartas mandadas para o irmão Quinto, indicado pelo Senado para ser pela terceira vez governador da província da Ásia, Cícero comenta a enorme quantidade de magistrados, assessores e familiares levados para lá por Quinto, para viabilizar seu trabalho de administração de uma das províncias mais lucrativas em termos de tributos para os romanos. Lembremos de Plínio, o Antigo, autor da História Natural, que morreu durante o governo de Tito, ao viajar para o Golfo de Nápoles para observar a erupção do vulcão Vesúvio. Sua obra reflete o conhecimento que produziu nas inúmeras viagens que empreendeu, visando ao estabelecimento de conhecimentos científicos. Lembremos dos professores\pedagogos, filósofos e sacerdotes que levavam seus conhecimentos de uma cidade e/ou região para outra. Por exemplo, as andanças de Apolônio de Tiana descritas por Filóstrato e os itinerários percorridos pelos filósofos descritos por Diógenes Laércio nas Vidas dos filósofos ilustres. Sabemos que muitas obras foram produzidas após viagens, e que em movimento os homens costumavam se corresponder. No sítio arqueológico de Vindolanda, um forte militar construído pelos romanos na Bretanha, foram encontradas inúmeras missivas formuladas e/ou recebidas pelos legionários. Plínio 
relata correspondências oficiais que trocou quando era governador com o imperador Trajano. O testamento de Otávio foi reproduzido em pedra em várias províncias, durante o governo do sucessor Tibério, usando como modelo as informações vindas de cartas e leis enviadas para os provinciais. Pergaminhos, tabletes de madeira e cerâmica, papiros, dentre outros suportes, serviram bem ao intento da ação de comunicação na Antiguidade latina. As cidades eram informadas oficialmente da visita dos príncipes e se preparavam para recebê-los, com construções a serem inauguradas e festas a serem oferecidas. Algumas moedas exibem em seus reversos algumas destas construções, que assim se tornavam conhecidas em outros lugares do Império. Dion Cássio oferece, na História Romana, alguns relatos de procissões efetivadas para receber e/ou se despedir de um príncipe em visita. Assim, notamos como as viagens e expedições dos imperadores movimentavam toda a vida social e econômica dos territórios envolvidos no itinerário.

7. Passemos, finalmente, a Lúcio Septímio Severo, nascido em Leptis Magna, um típico representante desta ordem senatorial proveniente das províncias norte-africanas. Na ocasião da ascensão de Dídio Juliano, após o famoso leilão do Império feito pelos Pretorianos em Roma, ele ocupa o posto de comandante militar das legiões da Panônia Superior e aproveitase desta posição estratégico-militar para reivindicar a púrpura. Desde que é aclamado 'imperator', boa parte de seu governo se passa longe da capital, em campanhas militares contra os rivais, Pescênio Níger e Clódio Albino, e em visitas às cidades norte-africanas e do Oriente. Você se debruçou sobre as viagens de Septímio a partir de Dion Cássio e Herodiano, poderia discorrer um pouco sobre elas?

R: Septímio viajou por várias províncias romanas antes mesmo de se tornar imperador, pois seu cursus honorum, efetivado durante os governos dos Antoninos, o levou a exercer várias funções administrativas civis e militares em regiões distintas. Após ser aclamado na Panônia, Severo realizou longa, mas rápida viagem a Roma, onde queria chegar antes de Pescênio. Dion Cássio ressalta que ele fez questão de mudar de roupas militares para civis antes de se apresentar no Senado e de conseguir também a aceitação senatorial. Após empreender a famosa reforma da guarda pretoriana, cujos membros foram responsabilizados pelo assassinato de Pertinax, de quem se proclamou vingador, Septímio empreendeu viagens pelos mais diversos motivos: combater Pescênio no Oriente; combater Albino na Gália; combater os partos; conhecer a tumba de Alexandre Magno no Egito; combater os bretões; dentre outras. Há uma enorme discussão acerca de uma possível visita ao Norte da África. Temos vários monumentos que foram erigidos esperando esta visita, que podem hoje ser estudados, contudo nem Herodiano nem Dion 
Cássio relatam esta viagem em pormenores, apenas a pretensão de realizá-la. Talvez os insistentes problemas de saúde do príncipe, que o impediam de ficar em pé tempo suficiente para aceitar do Senado uma procissão do triunfo, após a vitória pártica, o tenham também impedido de retornar à sua pátria, Leptis Magna, na atual Líbia, cuja guerra civil persistente tem me impedido de conhecer tão importante sítio arqueológico. No famoso arco dos Severos, no fórum romano, temos relevos retratando o movimento e as incursões militares de Septímio e de seus filhos, Geta e Caracala, contra os partos, além de belíssimas representações de vitórias aladas com coroas de louros na mão, marcando na pedra que tal construção foi erguida para comemorar uma grande vitória militar empreendida pelos romanos.

8. Quem eram, geralmente, os integrantes da comitiva imperial? Em termos logísticos, havia algum magistrado responsável por organizar os percursos, garantir as provisões necessárias da comitiva? Havia riscos implicados nessas viagens pelo Império, mesmo em se tratando do imperador?

R: Toda viagem, por motivos de turismo, religioso, bélico, comercial, dentre outros, sempre implicava em perigos. Os romanos ficaram conhecidos pela técnica de construção de estradas, que abrangiam e buscavam integrar todo território imperial, e vários fortes e cidades se estabeleceram às margens destas vias. Temos também a construção de tavernas e comércios afins de beira de estrada, que buscavam garantir a troca de cavalos para as charretes usadas nos deslocamentos, bem como alimentos e outros bens necessários aos viajantes. Com os persas, os romanos perceberam que estas estradas facilitavam o transporte de mercadorias, correspondências e pessoas. Ainda hoje pode-se percorrer parte da famosa Via Appia. Eram pelos cursos marítimos, fluviais e terrestres que fluíam ordens administrativas, magistrados, soldados, escravos, libertos, mercadorias em geral e bens de todas as naturezas. Ficaram conhecidos os piratas combatidos por Pompeu no Mar Egeu, os bandidos berberes do Norte da África e salteadores que enchiam várias vias romanas. Chegaram-nos leis escritas, em vários códigos e estelas, que buscavam combater estas mazelas. Eram os membros da aula Caesaris, os prefeitos da guarda pretoriana e os integrantes do consilium principis que costumavam organizar as viagens dos imperadores, que podiam ser realizadas para participar de uma contenda, para visitar um templo ou um monumento, para inaugurar uma obra pública, para conhecer um novo forte, para captar a cooperação das elites municipais, etc... Tudo era levado para garantir o bem-estar do príncipe e de sua comitiva: tendas para o pernoite, tapetes, estátuas, quadros, pratos, copos, talheres, camas, esteiras, almofadas, bancos, mesas, etc... Por isso, 
o movimento de um soberano despertava tanto interesse, visto que era quase o palácio em movimento para a visão dos súditos dentro e fora de Roma. Mas existiam viagens mais curtas e menos luxuosas, como as realizadas para participar de festivais em cidades próximas à capital. Cabia à cidade preparar a recepção ao soberano, com procissões festivas, banquetes e inaugurações. A saída para batalhas também contava com enorme efetivo militar e o uso de bigas e quadrigas sobre as quais saía o soberano em direção aos campos de batalha. Deste modo, percebemos como cada deslocamento se dava de uma forma, adequando-se ao motivo da viagem e às necessidades da empreitada. Acrescentese que havia embaixadas realizadas pelas autoridades locais elou seus representantes visando a convidar o soberano para uma visita, bem como para conhecer os gostos dos príncipes e poder acertar datas, locais e horários das cerimônias.

9. Você tratou em um artigo recente sobre a infância de Caracala e Geta, comente um pouco sobre a educação dos filhos de Septímio e Júlia Domna no contexto de uma 'domus' imperial itinerante.

R: Septímio era viúvo quando se casou com a filha mais velha de um importante sacerdote de Emesa. Ele conheceu Júlia Domna quando estava a mando do Império na Síria, como magistrado. Segundo Dion Cássio, havia o rumor na região de que ela seria esposa de um imperador... Ela passou a acompanhá-lo em todas as viagens, inclusive as militares, recebendo o título de Augusta. Carregava consigo os dois filhos pequenos, para que conhecessem a lida do soberano e para que fossem preparados para substituir o pai tanto nos negócios familiares quanto nos públicos. É interessante como Septímio preferiu homenagear o sogro, chamando seu primeiro filho homem de Bassiano, alcunhado posteriormente de Caracala, referência a um curto manto galês que o rapazote adorava ostentar. Seguindo as informações advindas de Herodiano, Dion Cássio, Eutrópio, Aurélio Vítor e das biografias da História Augusta, os dois herdeiros se detestavam, tanto que ocupavam alas separadas no palácio, em Roma, e tendas diferentes quando estavam em viagem. Ambos acompanharam o pai nas viagens ao Egito e à Bretanha, além das campanhas militares contra os partos, no Oriente. Júlia Domna organizou, segundo Filóstrato, um círculo de escritores, filósofos e pedagogos no palácio, no Palatino, para auxiliar na educação dos jovens, e alguns destes mestres acompanharam a esposa do imperador e seus filhos nas viagens, bem como os sempre presentes membros da guarda pretoriana.

10. Depois que foi aclamado imperador, Caracala promoveu vários jogos e deu início a construção do complexo suntuoso de banhos públicos que hoje conhecemos, porém, sua 
permanência na capital foi curtíssima. Até o momento de seu assassinato, em 217, passou a maior parte do tempo em incursões militares e viagens. Gostaria que tratasse das viagens de Caracala às cidades do Oriente, como Alexandria, Nicomédia, Antioquia, especialmente, a visita ao sítio de Tróia. Os templos e santuários aparecem neste percurso?

R: Segundo Dion Cássio, a única atividade pública que os dois filhos e herdeiros de Septímio conseguiram realizar juntos foram as cerimônias fúnebres do imperador, marcadas por uma viagem que conduziu as cinzas guardadas num belo vaso de alabastro de Eburacum até Roma, para que estas fossem depositadas no Mausoléu dos Antoninos, atualmente conhecido como Castelo de Sant'Angelo. Geta acabou assassinado a mando do irmão, que passou assim a governar sozinho. $O$ fratricídio e a promulgação do Edito Antoniniano que, em 212, concedeu a cidadania romana plena a todos os homens livres do território imperial, na busca de aumentar a arrecadação de impostos e a entrada de homens no exército, visto que Caracala pretendia empreender uma grande contenda militar contra os partos mais uma vez, fez com que o príncipe passasse a enfrentar uma grande oposição no Senado. Buscando arrefecer os ânimos em Roma, aumentar sua aceitação entre as elites provinciais, pedir a proteção divina, visitando vários templos, conhecer alguns comandantes militares e arrecadar fundos nas ricas cidades orientais para o empreendimento bélico na Pártia, Caracala visitou o Egito e as províncias da Bitína, da Síria e da Ásia, onde os publicanos sempre arrolavam grandes quantidades de tributos. O rumor do assassinato de Geta chegou antes de Caracala a Alexandria e ele não foi muito bem recebido, o que fez com que ele mandasse eliminar alguns dos cidadãos locais. Na Bitínia, buscou acalmar disputas regionais antigas entre as elites de Niceia e de Nicomédia, optando por favorecer esta última, o que causou revolta em Dion Cássio, nascido em território niceno. A visita ao que teria restado de Troia, na Ásia Menor, atual Turquia, acabou favorecendo a realização de cerimônias em memória de Eneias, herói troiano, responsável, segundo Virgílio, na Eneida, pela futura família dos fundadores de Roma, Rômulo e Remo. Caracala acabou assassinado a mando de seu prefeito do pretório, Opélio Macrino, quando voltava de uma viagem ao templo de Cibele, ao se afastar da comitiva para se aliviar atrás de uma moita...

11. Em sua pesquisa você trata dos preparativos para receber a comitiva imperial, comente um pouco, se possivel, sobre a cerimônia do 'adventus'.

R: O adventus é a chegada festiva de uma pessoa importante numa cidade. Temos os famosos relevos do arco de Septímio em Leptis Magna, que retratariam a chegada do 
príncipe à sua cidade natal. Como não temos provas suficientes para afirmar que esta visita realmente aconteceu, usamos estas imagens de uma forma geral, como representações comuns do que deveria ocorrer numa cerimônia de recepção de uma autoridade a determinada localidade. Além disso, temos moedas cujos reversos apresentam imagens das construções e de alguns rituais que eram realizados nestas festividades. Sabemos que o príncipe era recebido com uma procissão, em que os membros dos estratos sociais mais elevados da cidade (decuriões, equestres, sacerdotes, etc...) desfilavam numa ordem previamente acertada. Portavam suas melhores roupas e joias $e_{\text {, por }}$ vezes, eram acompanhados de esposas, filhos e demais familiares; comumente usavam incensos e coroas de flores, para aflorar os sentidos olfativos. Também era comum o uso de músicos para marcar a marcha da procissão festiva. Os alimentos do banquete eram exibidos em cestas e vasos de cerâmica, e também conduziam-se os animais que seriam abatidos em sacrifício para as divindades e depois teriam suas carnes consumidas nos convivia. Se fosse num período noturno, usavam tochas acesas. Ao final da procissão, normalmente numa biga ou quadriga, aparecia o imperador ladeado por alguns familiares e protegido pelos pretorianos. Era a chance de os provinciais verem pessoalmente seu mais alto magistrado, que residia comumente na capital, e das autoridades locais buscarem a concessão de benesses.

12. Os especialistas da área têm lidado recentemente com a onda de 'cancelamentos' e acusações de eurocentrismo no que concerne aos conteúdos de História Antiga. Recordo-me que, na primeira versão da BNCC, de 2018, a Antiguidade foi quase extirpada do currículo escolar. Para alguém que pesquisa uma dinastia de imperadores de origem africana $e$ síria, essas críticas, minimamente, procedem? Qual a sua percepção do Império Romano, especialmente no recorte do século III?

R: Costumo comentar com os alunos que quanto mais estudo os romanos mais entendo o Brasil. Exercer a observação sobre o outro, identificando características de alteridade que devem sempre ser respeitadas, é uma atividade de extrema importância. A resiliência é despertada pelo interesse pelo diverso. Não se consegue lidar bem com aquilo que não se está aberto para conhecer. E conhecer sem julgamentos, sem definição de parâmetros equivocados de melhor ou pior. Acredito ser viável utilizar o conhecimento construído acerca do mundo antigo, tanto ocidental quanto oriental, para revermos e ressignificarmos noções acerca do desenvolvimento da cidadania, da democracia, da liberdade de expressão. Na tese que defendi para promoção à professora titular na UFG, abandonei um pouco os Severos para me dedicar à poesia do cristão Prudêncio e 
verificar como este autor se assenhoreou de conteúdos e formatos vindos da pedagogia clássica para fomentar o proselitismo cristão. Para converter pessoas aos princípios da fé cristã, Prudêncio percebeu que precisava falar a língua de seu povo, ou seja, necessitava usar referências advindas do mundo pagão, que eram reconhecidas pelos seus leitores/ ouvintes. Nós ainda reconhecemos referências produzidas na Antiguidade e elas podem servir para formarmos nossos alunos. No cinema, na literatura, nas séries de TV, a Antiguidade ainda nos estimula a pensar e a refletir sobre o nosso próprio tempo. Minha pesquisa atual sobre a obra de Cipriano de Cartago, primeiro bispo a ser martirizado e morto no Norte da África, demonstra como a dificuldade em lidar com o diverso pode gerar efeitos catastróficos. Cipriano acabou tendo que viajar para fora de sua cidade natal ao ser perseguido por membros de sua própria comunidade e depois exilado a mando de um edito imperial. Sua última viagem foi em direção ao reino celeste, morto ao não ser aceito pelas autoridades vigentes. Uma grande pestilência, como a que enfrentamos hoje, se abateu sobre o Norte da África e o bispo buscou fornecer, em sua obra, alento aos necessitados. Ontem como hoje é o caminho da arte da escrita e da representação o mais suave para deambular pelos territórios ocupados pelos seres humanos. 